\begin{tabular}{lll} 
KULTURA & $\begin{array}{l}\text { POLSKA A KADEMIA NAUK } \\
\text { KOMITET SOCJOLOGII }\end{array}$ & ISSN 0023-5172 \\
i & $\begin{array}{l}\text { INSTYTUT STUDIÓW POLITYCZNYCH } \\
\text { SPOLECLENSTWO nr } 2016, \text { WIDZIANE W MIEŚCIE }\end{array}$ & \\
\hline
\end{tabular}

WALDEMAR RAPIOR

Uniwersytet im. Adama Mickiewicza w Poznaniu

\title{
JAK BUDOWANA JEST PRZESTRZEŃ PRYWATNA WE WSPÓŁCZESNYM MIEŚCIE?
}

\section{ANALIZA DZIENNIKÓW WIZUALNYCH}

Zacznę od wzmianki osobistej. Kiedy rozmawiam z moimi sąsiadami, słyszę narzekania na obcość ulicy, na której mieszkamy. Ale nie kwapią się oni do jej udomwienia, gdyż wymagałoby to zrobienia miejsca dla ławek, stołów, trawników dla zwierząt. Argumentują, że zniknęłyby parkingi, na których stawiają swoje auta. Chcąc poczuć się bezpiecznie, pragną miejskiego monitoringu. Jest to typowy argument zwolenników grodzonych osiedli (zob. Shenker 2015). Zadałem sobie pytanie: czy obcość ulicy, o której mówią moi sąsiedzi, nie wynika $z$ zachwiania równowagii między przestrzenią publiczną (dostępną dla każdego) a przestrzenią prywatną. Monitorowanie miasta czyni $z$ jego użytkowników przedmiot publicznych wizerunków. Jednocześnie jedną z najbardziej intymnych i prywatnych czynności stało się dziś filmowanie i dzielenie się via internet niemal każdym etapem życia, nawet banalnymi, codziennymi sprawami (por. Illouz 2010). Zastanowię się tu nad problemem równowagi między intymnością a wizerunkiem publicznym. Podążając między innymi za Ervingiem Goffmanem, pokażę, że współwystępowanie prywtnego i publicznego jest wyznacznikiem współczesnych zachodnich miast. Równowaga między nimi została zachwiana - jak twierdzą niektórzy (zob. Atwood 2013) - przez wszechobecność systemów monitorujących funkcjonowanie ludzi i miast (kamer CCTV, aplikacji internetowych, systemów GPS itd.). Zastanawiając się, jak ludzie budują przestrzeń prywatną „pod okiem kamery", przejrzałem raz jeszcze raport z badań nad uczestnictwem 
w kulturze, w których jako technikę badawczą zastosowano dzieniki wizualne ${ }^{1}$.

\section{Z KAMERĄ/SMARTFONEM WŚRÓD LUDZI: „JA” JAKO PRZEDMIOT EKSPOZYCJI}

W latach 2010-2013 podczas kolejnych edycji teatralnego Festiwalu Malta przekazaliśmy szesnastu osobom minikamerę wideo. Miała ona posłużyć im do dokumentowania zdarzeń, w których uczestniczyli, rozmów, które toczyli, ukazania siebie samych oraz innych w kontekście festiwalu. W raporcie sporządzonym na podstawie tych badań napisaliśmy:

„Nie codziennie chodzimy po mieście z kamerą filmując sami siebie. Świat pochłonięty przez kamerę składa się z czynności pisania maili i SMS-ów o spektaklach [teatralnych] lub swoich wrażeniach z nimi związanych; z przypadkowych spotkań $z$ aktorami i kuratorami w różnych punktach miasta; filmowania skupisk ludzi tam, gdzie ich zwykle/najczęściej nie ma (np. kąpiących się w fontannach, koczujących w kolejkach przed wejściem do jakiegoś budynku etc.), ale też np. zmywania naczyń, częstowania papierosami, siedzenia w klubie festiwalowym, remonty uliczne, opalania się na pomoście, zakupy żywności (jak i wszelkie inne sprawunki). Osoby prowadzące dzienniki doświadczały miasta i festiwalu jako integralnych części” ${ }^{2}$.

Dziś opis ten wydaje się jak najbardziej aktualny, $z$ wyjątkiem jednego zdania - pierwszego. Chodzenie po mieście $z$ kamerą (lub smartfonem) i filmowanie samego siebie stało się codzienną i powszechną praktyką. Osoby prowadzące dziennik wizualny oraz ludzie przez nich filmowani zostali postawieni w sytuacji, która wymaga od nich zmierzenia się z kamerą, ze świadomością prezentacji publicznej siebie i innych ludzi. Nie jest to już sytuacja szczególna, gdyż rozrost internetu spowodował, że każdy z nas stał się przedmiotem ekspozycji. Edward Mendelson (2016) parafrazując na poły tylko żartobliwy aforyzm Virginii Woolf (,w albo w okolicach grudnia, 1910, ludzka natura się zmieniła"), stwierdza, że w albo w okolicach grudnia, 2010, natu-

\footnotetext{
${ }^{1}$ Piotr Luczys, Waldemar Rapior, „Uczestnictwo w kulturze w działaniu: dzienniki wizualne jako metoda badania uczestniczenia w kulturze. Raport z badań 2011-2013". Tekst poniższy jest zmodyfikowaną wersją niektórych części tego raportu. Powstałe w toku opisanych badań dzienniki wizualne maiały posłużyć odtworzeniu i połączeniu pojedynczych biografii osób, które stykają się ze zdarzeniem kultury instytucjonalnej. W roku 2011 - zrealizowano 5 takich dzienników, w 2012 - 7, a w 2013 - 4. Na zbiór owych szesnastu dzienników wizualnych złożyło się w 2011 roku 357 filmów, w 2012 - 516, a w 2013 - 198 filmów. Łącznie daje to sumę 1071 filmów (w tym 26 filmów z wywiadów) nakręconych przez szesnaście osób biorących udział w badaniach na przestrzeni lat 2011-2013. W tych latach badania były realizowane w ramach programu Obserwatorium Kultury MKiDN. W internecie są dostępne: dzienniki wizualne (http://tworzeniekultury.pl/dzienniki.html) oraz raport z badań (https://www.academia. edu/12357212/Młodzi_i_teatr._Szanse_i_bariery_na_przykładzie_Wielkopolski).

2 Tamże.
} 
ra ludzka zmieniła się, gdy wszyscy, jak się wydaje, zaczęli nosić przy sobie smartfon.

Prywatność dziewiętnastowiecznego członka burżuazji i dwudziestowiecznego przedstawiciela klasy średniej znajdowała się pod określonym adresem - numerem mieszkania, kodem pocztowym. Dziś każdy może być dostępny dwadzieścia cztery godziny na dobę. Uczestniczenie w kulturze dla wielu oznacza ekspozycję siebie on line, tekstualizację i wizualizację swojej prywatności (Illouz 2010).

Dzienniki wizualne z naszych badań są zapisem tego, jak ludzie w różnym wieku, różnej płci, o różnym kapitale kulturowym i społecznym radzili sobie $z$ wszędobylskim okiem kamery. Zadaniem osób prowadzących te dzienniki było tworzenie „notatek uporządkowanych” (filmowanie otoczenia co trzy godziny) oraz „notatek-impresji” (filmowanie tego, co i jak chce „dziennikowiec” osoba prowadząca dziennik) ${ }^{3}$. Kamera - jako przedmiot materialny oraz jako dystrybutor wizerunków do świata wirtualnego - wtargnęła w życie „dziennikowców". Medializacja tego, co prywatne (czyli de facto upublicznienie prytwatności i intymnych gestów „dziennikowieców”), wywołuje reakcję ochronną. Wyróżniliśmy dziesięć strategii ochrony prywatności oraz "Ja” własnego $\mathrm{i}$ innych $\mathrm{w}$ kontakcie $z$ niemal całodobowym monitoringiem kamery. Strategie te są dynamicznym procesem godzenia przestrzeni prywatnej z przestrzenią publiczną.

W miejscach publicznych jednostki, aby dbać o własny wizerunek w oczach innych, muszą swym zachowaniem pokazać, że mają jakiś cel - może on zejść na drugi plan (np. u fryzjera czekając na swoją kolej można sięgnąć po gazetę), choć musi być jasne, że jednostka jest zawsze gotowa do realizacji celu głównego (tj. do porzucenia bez żalu czytanego artykułu, gdy fryzjer zawoła „Następny!”) (zob. Goffman 2012). Mówiąc inaczej, jednostki w miejscach publicznych mają zajmować się swoimi sprawami. Oznacza to, że osoby trzecie $\mathrm{w}$ normalnych sytuacjach nie powinny ingerować $\mathrm{w}$ to, co robią obcy ludzie. Goffman nazywa wymóg nieingerencji uprzejmą nieuwagą. Jednocześnie miejsca publiczne wykluczają pewne zachowania pod groźbą sankcji - zakłopotania, zawstydzenia, kłopotliwej utraty kontroli nad własnym wizerunkiem. Jednostka w miejscach publicznych zobowiązana jest do przestrzegania wymogu

3 Większość „dziennikowców” swobodnie łączyła „notatki uporządkowane” z „notatkami-impresjami”, traktując instrukcję do tworzenia dziennika wizualnego jako zestaw raczej myśli przewodnich niż sztywnych reguł. W roku 2011 liczba filmów zrealizownych przez jedną osobę wahała się od 46 do 109, w 2012 — od 26 do 142, a w 2013 — od 13 do 105. Swoboda realizacyjna z pewnością sprzyjała uzyskaniu ciekawego materiału do analizy praktyk uczestnictwa, ale nie pozwoliła na zaprezentowanie sumarycznych podsumowań. Jedną z niewielu wyraźnych cech charakteryzujących grono szesnastu realizatorów badań jest fakt, że znalazło się w nim aż dwanaście kobiet i tylko czterech mężczyzn (może być to jednak tylko konsekwencja zastosowanej metody doboru badanych, który odbywał się w gronie „znajomych” oraz „dalszych znajomych”, na zasadzie poszukiwania „chętnych / zainteresowanych”). 
minimalnej samokontroli i opanowania ${ }^{4}$. Podstawowy wymóg miejsc publicznych (posiadanie celu i demonstracja tego postawą ciała, gestami, mową) nakłada jednocześnie na uczestników sytuacji publicznej zobowiązanie uprzejmej nieuwagi (pokazania, że cel został zauważony, aby chwilę potem dać do zrozumienia, że inni ludzie nie budzą szczególnego zainteresowania patrzącego). W teorii Ervinga Goffmana zachowania w miejscach publicznych są delikatną i chwiejną równowagą między niepatrzeniem, taktem a dostrzeganiem, zwracaniem uwagi.

Praktyki „dziennikowców” są przykładem utrzymywania delikatnej równowagi między kulisami a sceną w świecie nasyconym mediami elektronicznymi. Przedstawię tu praktyki budowania przestrzeni prywatnej i równowagi między nią a przestrzenią publiczną. Tłem opisu tych praktyk będzie miasto.

\section{URZĄDZENIE TECHNICZNE: OD MEDIATORA DO POŚREDNIKA}

Kamera Flip, którą otrzymali od nas „dziennikowcy”, jest łatwa w obsłu$\mathrm{dze}^{5}$. W ręce Krzysztofa ${ }^{6}$ (wiek 40-50 lat, wykształcenie wyższe), z mediatora (Latour 2010, s. 55-58), czyli aktywnego obiektu o niepewnym statusie, który wymusza działanie w celu określenia jego roli (przyciskanie guzików metodą prób i błędów, oglądanie kamery, układanie jej w dłoni, próbne filmowanie), staje się przedmiotem bezproblemowym, bezdyskusyjnym, realizującym wolę $\mathrm{i}$ intencję człowieka - zmienia się w pośrednika ${ }^{7}$. Krzysztof pierwszego dnia festiwalu filmuje wszystko: gdzie przebywa, dokąd zmierza, co ogląda, gdzie pracuje, $z$ kim się spotyka. Następnego dnia pokonuje ostatni bastion mediacyjny kamery, jak mówi - „opór materii”. Podłącza ją do komputera i ogląda dziennik wizualny. „Są, działają [notatki wizualne], a jeszcze wczoraj takiej pewności nie miałem" - mówi. Kamera, nawet na poziomie zapisanego materiału, nie jest już dla Krzysztofa mediatorem — wszystkie jej niewiadome zostają odkryte, nie musi się już o nic martwić (że coś nie działa, że gdzieś

\footnotetext{
${ }^{4}$ Wymóg ten zależy od statusu osoby: od czterolatka nie żąda się takiej kontroli ciała i myśli jak od czterdziestolatka; osoba będąca wyżej w hierarchii społecznej może sobie pozwolić na więcej niż ktoś usytuowany niżej.

${ }^{5}$ Panel składa się z czerwonego guzika nagrywania i przycisku z symbolami strzałek (przeglądanie materiału) oraz „, " i „,-" (zoom in i zoom out oraz regulacja głośności). Niewielkie wymiary kamery sprawiają, że łatwo mieści się w torbie na ramię bądź kieszeni spodni.

${ }^{6}$ Niektóre imiona zostały zmienione.

7 Pośrednik i mediator „są tym, co skleja działających aktorów w pewną całość, co między nimi pośredniczy, a tym samym umożliwia działanie, jeżeli uznamy, że zawsze jest ono cechą relacji, która wiąże ze sobą różnorodne elementy. O ile jednak pośrednicy po prostu przenoszą siłę, komunikat, wolę lub intencje, zasadniczo ich nie przekształcając, o tyle mediatorzy je negocjują, zniekształcają, modyfikują, stając się tym samym aktywnym elementem działania" (Krajewski 2013, s. 57).
} 
źle naciśnie, że coś się nie nagrało). Kamera może już pełnić rolę pośrednika, wykonawcy intencji Krzysztofa.

\section{KATALIZATOR ŚWIADOMOŚCI I PORZĄDEK NAWYKÓW: POŚREDNIK ZNÓW STAJE SIĘ MEDIATOREM}

Krzysztof stara się wpasować w ramówkę projektu badawczego. Około godziny dziesiątej rano przedstawia sprawozdanie z poprzedniego dnia: „nie oszukujmy się. Prowadzenie dzienniczka nie jest prostym zajęciem. Myślałem, że będzie lepiej, że będzie prościej, a tutaj się okazuje, że, no — pewnie nie każdy może tak internetowo prowadzić, zdecydowanie łatwiej mi by było pisać. Ale nająłeś się za psa, to szczekaj, mówi stare powiedzenie" ${ }^{8}$. Znajomość obsługi urządzenia nie przekształca automatycznie mediatora w pośrednika, czyli bezproblemową czarną skrzynkę, do której nie trzeba zaglądać, bo po prostu się z niej korzysta. Kamera i konieczność jej użycia w ramach poleceń danych przez badacza sprawiają Krzysztofowi trudności związane z przyzwyczajeniami („wolałbym pisać”), ale też z filmowaniem swojego wizerunku oraz wprowadzeniem kamery do grupy osób, z którymi spędza czas („weź odpuść” — mówi jedna $z$ jego znajomych).

Dzienniki wizualne odtwarzają wzór zachowań, który jednostka często uświadamia sobie post factum. Krzysztof po obejrzeniu notatek wizualnych nazywa swoje filmy „bzdurami”. Aleksandra (20-25 lat, średnie) prosi nas, aby nie zamieszczać w sieci kilku filmików, gdyż uważa, że dyskusja, jaką toczy z przyjaciółkami przed kamerą, może przedstawić ją i jej koleżanki w niekorzystnym świetle. Ewelina (40-50 lat, wyższe) przerywa filmowanie, gdy wzmaga się atmosfera kłótni. Kamera jest katalizatorem świadomości. Zdarzenia przefiltrowane przez jej wizjer zaczynają nabierać kształtu - znaczyć, mieć jakąś formę, jakieś konsekwencje, wywołują zakłopotanie lub entuzjazm.

Kamera to nie tylko urządzenie techniczne, a prowadzenie dziennika wizualnego to nie tylko czynność filmowania. Realizacja dzienników wizualnych wprowadza nowy porządek nawyków i rutyny dnia codziennego - dokumentacji otoczenia, a więc uznania, że coś jest warte sfilmowania, utrwalenia i zapamiętania rzeczywistości; rejestracji siebie samego, a zatem również pewnej formy autoprezentacji; zwiększonej autorefleksyjności wobec otoczenia; udawanej lub autotelicznej spontaniczności. Gdy okazuje się, jakie oczekiwania są związane $z$ filmowaniem - translacja sfery prywatnej $\mathrm{w}$ publiczną, filmowanie co trzy godziny, dokumentacja rzeczywistości i życia kamera $z$ prostego narzędzia staje się dla Krzysztofa kłopotliwym mediatorem.

${ }^{8}$ Zob. https://vimeo.com/48251142 


\section{OSWAJANIE MEDIATORA: \\ WSPARCIE ZNAJOMYCH I BYCIE KONSEKWENTNYM}

Ewelina, podobnie jak Krzysztof, narzeka na kamerę: „to nie jest moja taka potrzeba filmowania, ujmowania co chwilę rzeczywistości” ${ }^{9}$. Gdy wypowiada te słowa, pojawia się, mimowolnie, gest trzymania kamery Flip w ręce. Gest ten jest charakterystyczny — kamerę Flip trzyma się zazwyczaj jedną ręką, a jej lekkość i wielkość nie krępuje ruchu ${ }^{10}$. Ciało Eweliny nauczyło się schematu operacyjnego kamery. Na poziomie cielesnym kamera nie stanowi już kłopotu. Problem pojawił się na poziomie wyobraźni: „cenię fotografię i ludzi, którzy się tym zajmują, [ale] drwię z ludzi, którzy siedzą na plaży i non-stop filmują swoje dzieci. I myślę sobie - ludzie nie żyjecie $z$ tymi dziećmi w tym momencie". Według Eweliny kamera zapośredniczyła żywe, autentyczne, bezpośrednie interakcje międzyludzkie. Podobnie myślą jej znajomi: ,jak wyciągnęłam kamerę, to ktoś mówił: a ty znowu chcesz kręcić, i siup - Ewelina pokazuje ręką gest spadającej gilotyny — wszystko siadało".

Niespójność między idiomami ciała a słowami jest ważnym wskaźnikiem dla badacza. Goffman powtarzał, że w sytuacji spotkania zakłopotanie pojawia się, gdy któraś z osób nie skupia uwagi na formalnym przedmiocie rozmowy. Ewelina skupiała się na rejestracji sytuacji, a nie na sytuacji samej w sobie. Przegląajając dzienniki dostrzegamy: czyiś wzrok badający to, co robi Ewelina, albo chwilę ciszy. Te drobne gesty są odczytywane przez Ewelinę. Ania (40-50 lat, wyższe), jej koleżanka, która namówiła ją do wzięcia udziału w badaniu, w takich sytuacjach zachowuje się naturalnie, jakby nigdy nic. Opowiada, wspomina, śmieje się. Konsekwentnie nie zauważa kamery - jej spontaniczność udziela się pozostałym osobom, więc pomału zaczynają uznawać nową rolę Eweliny.

Presja społeczna („a ty znowu chcesz kręcić”) jest w przypadku Eweliny na tyle silna, że mówi: „miałam taki moment zbrzydzenia”. Wiąże się on z tym, że przez kamerę nie mogła $\mathrm{w}$ pełni zaangażować się w spotkanie. Spotkanie jest systemem społecznym, który powstaje, gdy bezpośrednio obecne są dwie osoby lub więcej i utrzymują pojedyncze ognisko zaangażowania. Tym ogniskiem uwagi zwykle jest temat rozmowy, wymiana gestów, słów i pauz między rozmówcami. Ewelina skupia się na filmowaniu, więc odcina się od wymiany cielesnej i dźwiękowej, od pozostałych współuczestników sytuacji. Jednak pozostaje jego częścią - często śmieje się zza kamery. Wymiana kodów cielesnych nie jest bezpośrednia, ale dzięki konsekwencji Ani, grupa zaakceptowała Ewelinę z kamerą i jej podzielną uwagę: skupienie się na spotkaniu, a zarazem na filmowaniu. Więcej — rozmówcy zaczynają wykorzystywać fakt, iż Ewelina pełni rolę operatora: zaczynają żartować z kamery, wygłaszać do kamery mono-

${ }^{9}$ Zob. http://vimeo.com/33798592

10 Zob. http://vimeo.com/33798592\#at $=0$ 
$\log { }^{11}$. Ewelina jest jednocześnie zewnętrznym i wewnętrznym obserwatorem, ważniejsze jest jednak to, że konsekwencja Ani w akceptacji nowego statusu Eweliny spowodowała jej zaakceptowanie przez pozostałych znajomych.

Jest w dzienniku Eweliny film, który dobitnie pokazuje akceptację jej podwójnego statusu i zniwelowanie dystansu między nią a jej znajomymi. Cała rzecz odbywa się w kolejce do przenośnych toalet ToyToy instalowanych podczas imprez masowych na otwartym powietrzu. Ewelina wyciąga kamerę ${ }^{12}$. Pierwsza reakcja - pauza znajomego Eweliny. Ale Ania jest na posterunku: „Mówię ci Ewelina, co to są za historie!”. Spontaniczność Ani zachęca znajomego, który właśnie umilkł, do kontynuacji dyskusji. Toczy się ona płynnie dalej, a kamera zachęca Ewelinę, by niczym wytrawny reporter zadawała pytania przypadkowym osobom, które wchodzą w tę grę i jej odpowiadają.

\section{UNIK: ANTYCYPACJA I BÓL SPOŁECZNY}

Kamera, jako przedmiot, nie zagraża naszemu ciału. Chociaż może znajdować się blisko twarzy, nie zaatakuje jak dzikie zwierzę chroniące swego terytorium. Często pojawia się pytanie filmowanego: „gdzie to [materiał wideo] będzie użyte?".

Reakcja emocjonalna na kamerę, antycypująca potencjalne zagrożenie, zakrycie twarzy lub zdziwiony, dopytujący wzrok, nie jest reakcją na bezpośredni atak, lecz na atak wyobrażony - potencjalne konsekwencje związane z rejestracją wizerunków: utrata nad nimi kontroli oraz brak możliwości ochrony swojego statusu. Reakcja emocjonalna nie dotyczy zagrożenia cielesnego, życia albo bólu fizycznego, lecz życia lub bólu społecznego - jest przedmiotem troski nie tyle o ciało biologiczne, ile o "Ja" społeczne.

Utrata kontroli, wspomniany „ból społeczny”, odnosi się do zwiększonego prawdopodobieństwa szerokiego odbioru filmów w kontekstach społecznych i sytuacyjnych innych niż te, w których filmy te są one tworzone. Zapis wideo odrywa się od sytuacji, w której powstał, a tylko tę sytuację jednostka może w miarę kontrolować. Nie ma ona wpływu na to, co stanie się z filmem później i jak będzie on interpretowany. Żyjąc wspólnie $z$ innymi zawsze podlegamy kontroli czy ocenie, ale $\mathrm{w}$ większości przypadków zdajemy sobie sprawę przynajmniej z tego, w jakim kontekście ta ocena przebiega i jakie części naszej roli czy tożsamości są oceniane czy krytykowane. W przypadku osób filmowanych można podejrzewać, że nie wiedzą one $\mathrm{w}$ jakim kontekście analizowane będą ich zachowania i postawy. To sprawia, że strach czy zakłopotanie związane $z$ poddaniem się zapisowi kamery, filmowaniem, $w$ wielu przypadkach są dość intensywne.

11 Zob. http://vimeo.com/34043259

12 Zob. http://vimeo.com/34076139 
Fakt ten sprawia, że działania filmowanych osób, czy nawet oni sami, stają się przedmiotem oceny tych, którzy się im przyglądają, a zatem nie tylko przyjaciół i znajomych, którzy są wśród nich, ale również tych, którzy zasiądą do biurek i po pewnym czasie, $\mathrm{w}$ innym kontekście sytuacyjnym, będą analizować filmy. Można stwierdzić, że te osoby, które unikają kontaktu z kamerą lub okazują wyraźne zakłopotanie, gdy się je filmuje, mogą czuć strach przed utratą kontroli nad oceną swojego zachowania dokonywaną pod ich nieobecność oraz w oderwaniu od sytuacji, w której zakorzenione było ich zachowanie.

\section{TAKT: SYTUACYJNE PRZEPLATANIE SIĘ KULIS I SCENY}

Zachowaniem łączącym kulisy i scenę jest takt — umiejętność niepopadania $\mathrm{w}$ zakłopotanie oraz niedopuszczenie, aby zakłopotani byli partnerzy interakcji (Goffman 2006, s.104). Ewelina wyłącza kamerę, gdy słyszy, że w natłoku spraw, pośpiechu przed koncertem, liczby osób w mieszkaniu i rozrzuconych po nim przedmiotów, pojawia się napięcie, rozdrażnienie, dysonans wywołany odmiennym podejściem różnych ludzi do porządku i chaosu. Poczucie taktu zależy od norm grupowych. Ola (25-30 lat, wyższe) przeklina i od razu pyta, czy przekroczyła reguły nie tyle jej grupy, ile szerszego kontekstu: „czy można przeklinać na tym filmie?”. Agata (25-30 lat, wyższe): „można”. Agata nie wyłącza kamery, gdyż normy językowe grupy są według niej ważniejsze od norm językowych szerszego kontekstu społecznego. W ten sposób to, co prywatne, zazębia się w to, co publiczne, a dyskusja między Agatą i Olą może dalej toczyć się $\mathrm{w}$ wysokiej temperaturze ${ }^{13}$.

Jedna $z$ notatek wizualnych $\mathrm{w}$ dzienniku Andrzeja (30-35 lat, wyższe) przedstawia grupę młodych osób spożywających alkohol w miejscu publicznym. Andrzej uspokaja swoich znajomych: „Dla pocieszenia, jeżeli nie chcecie być na filmie, że pijecie alkohol, powiem wam, że jest bardzo ciemno i nic nie widać". Robi to $\mathrm{w}$ formie żartu, co oznacza, że zna reguły prawne, a także wie, że kamera może niepokoić osoby przestrzegające prawa, pokazując jednocześnie, iż jest istotą wolną, dla której w tym momencie nie są ważne normy prawne, lecz dobra zabawa i reguły towarzyskości ${ }^{14}$. Filmuje, ale zapewne, gdyby pojawił się protest, wyłączyłby kamerę.

\section{KONWENCJA ZDARZENIA/PROJEKTU}

Udział w projekcie zmieniał status uczestników - stawali się oni „dziennikowcami". Ci, którzy prowadzili dziennik wizualny, wchodzili w rolę wyznaczoną przez projekt dzienników wizualnych, włączając w logikę projektu również osoby, z którymi się stykali. Na przykład Agata pytała wciąż, „która jest

13 Zob. http://vimeo.com/63670601

14 Zob. http://vimeo.com/33988496 
godzina?" ${ }^{15}$. Zapytanie to stało się hasłem podkreślającym, iż „ja, Agata, oraz wy, moi przyjaciele, znajdujemy się teraz w konwencji projektu badawczego". Początkowo ciągłe dopytywanie się Agaty o godzinę irytowało jej znajomych. Szybko jednak zapytanie o godzinę stało się dominantą uczestnictwa Agaty w projekcie i tematem żartów. Konwencja projektu stała się osłoną prywatności, sposobnością do świadomego odgrywania roli filmującego i filmowanego.

Konwencja projektu z jednej strony eksponuje prywatność (rozmowy, gesty, sytuacje itd.), z drugiej — zakrywa ją poprzez wyolbrzymienie jednego z zadań, jakie stało przed twórcami dzienników. Hasło „która jest godzina” ${ }^{16}$ przypominało o zadaniu, które wykonuje Agata — prowadzenie dziennika, a zarazem pozwoliło zbudować dystans i zaznaczyć spontaniczne zaangażowanie w quasi-rzeczywistość projektu.

\section{POZA KULISY I SCENE: NAWIGACJA MIĘDZY KONWENCJAMI}

Gosia (20-25 lat, średnie) i Jacopo (25-30 lat, wyższe) idąc, trzymają się za ręce, szepczą coś sobie do ucha - tworzą zamknięty, intymny krąg. Agata podąża za nimi z włączoną kamerą. Gosia dostrzega kamerę i zaczyna się uśmiechać ${ }^{17}$. Para spontanicznie przechodzi z konwencji intymnej, prywatnej w publiczną - dostępną dla Agaty i dla kamery, czyli dla wszystkich. Kontrola idiomatyki ciała zależy od czujność, uwagi, spostrzegawczości - kamera tłumaczy to, co prywatne, intymne na to, co publiczne, dostępne dla ogółu.

Magdalena (30-35 lat, wyższe) z włączoną kamerą przechadza się po korytarzu Starego Browaru. Oko kamery prześlizguje się po publiczności czekającej na prezentację tańca. Gdy zatrzymuje się na chwilę na grupie znajomych, dostrzegłszy nakierowaną na nich kamerę, przełączają się z konwencji prywatnej w publiczną. Oznajmiają to takie symptomy, jak: uśmiech pojawiający się na twarzy, wzrok skierowany w kamerę, zmarszczone brwi, zaciekawienie, ruchy głowy przypominające otrząsanie się $\mathrm{z}$ drzemki ${ }^{18}$, zastygnięcie czy niewzruszony brak reakcji i kontynuowanie dotychczasowej interakcji (choć ze świadomością, że jest się filmowanym). Wszystkie te oznaki świadczą, iż kamera wprowadza w sytuację dodatkową publiczność. Nie jest to jednak publiczność, którą definiują fizyczne właściwości tu i teraz, lecz publiczność wyobrażona, której cech osoby filmowane nie mogą zidentyfikować: ani ich wieku, ani płci, ani statusu ekonomicznego lub społecznego. Filmowani w tych przypadkach fizycznie znajdują się w sytuacji osobniczej (faza bliższa to odległość od 45 do $75 \mathrm{~cm}$; faza dalsza: odległość od 0,75 do $1,2 \mathrm{~m}$ ), ale działają podług sytuacji publicznej (odległość od 3,6 $\mathrm{m}$ do ponad 7,5 m).

\footnotetext{
15 Zob. http://vimeo.com/63456944

16 Zob. http://vimeo.com/63642399

17 Zob. https://vimeo.com/64224167

18 Zob. https://vimeo.com/49930745
} 
Powyższe przypadki to przykłady kolejnej strategii ochrony prywatności: umiejętności przechodzenia między konwencjami. Prywatność nie jest miejscem odosobnionym, a ochrona prywatności odbywa się w czasie, poprzez działanie, a nie oddzielenie przestrzenne kulis i sceny. Konwencja - intymna, prywatna, publiczna, wyobrażeniowa - jest formą upubliczniania prywatności.

Basia (20-25 lat, średnie) spóźnia się z włączeniem kamery. Prosi swojego przyjaciela o powtórzenie do obiektywu tego, co przed chwilą powiedział ${ }^{19}$. Ten opowiada o obejrzanym przed chwila spektaklu raz jeszcze, lecz tym razem kokietując Basię jako operatorkę. Prywatność w takich sytuacjach nie jest tuszowana, zakrywana, odłączana, chowana za kulisami, lecz ujmowana w konwencję. Taka interakcja sprawdza się wówczas, gdy obie strony, operatorzy i aktorzy, improwizują w takt i rytm wypowiadanych słów, wykonywanych gestów. Skrępowanie pojawia się, gdy konwencje - filmowania i odgrywania - wpadają w kolizję. Taka sytuacja zdarza się wówczas, gdy filmujący wykorzystuje przewagę nad rozmówcą, jaką daje mu kamera (np. kontrola wizerunku na filmie). Gdy operator nie gra roli obserwatora zewnętrznego, lecz sam reaguje na działania i konwencje innych osób, interakcja przebiega płynnie.

\section{PUBLICZNOŚĆ ZA BIURKIEM: TAKT ZEWNĄTRZGRUPOWY}

Następną strategią ochrony prywatności jest takt zewnątrzgrupowy. Tracimy kontrolę nad prywatnością, gdy materiał wideo $z$ naszym udziałem zaczyna cyrkulować w sieci. Takt zewnątrzgrupowy zależy od osób trzecich, nieuczestniczących bezpośrednio w filmowanej sytuacji. Siedząc przed ekranem komputera i oglądając dzienniki wizualne, mamy dostęp do spontanicznych zachowań widzów festiwalu. Interpretacja tych zachowań leży w naszych rękach. Takt zewnątrzgrupowy odwołuje się do naszego „Ja”, osób, które oglądają dzienniki, poczucia przyzwoitości, a jednocześnie do umiejętności nie bezinteresownego, bezosobowego odbioru, lecz traktowania wizerunków oraz ich nośników — obrazów, zdjęć, słów i wideo — jako doświadczenia życiowego.

\section{PRZYWIAZZANIE AFEKTYWNE: \\ WSPÓŁUDZIAŁ W KONTROLOWANIU SYTUACJI}

Ola (20-25 lat, średnie) rozpoczyna dziennik wizualny od przedstawienia głównych jego bohaterów: swojej siostry - Agaty (20-25 lat, średnie) oraz siebie. Agata uśmiecha się, kłania i wita z publicznością („witam serdecznie”), po czym spuszcza wzrok i dodaje „kręcisz tylko z jednej strony”. Agata szybko

19 Zob. https://vimeo.com/33595454; https://vimeo.com/33689067 
pojmuje aluzję i odwraca kamerę w swoją stronę: „a to jestem ja”. Na twarzy Agaty znów pojawia się uśmiech ${ }^{20}$.

Edward J. Lawler (2009, s. 176) twierdzi, że wraz ze wzrostem lub zmniejszeniem stabilności i możliwości kontroli sytuacji zwiększa się prawdopodobieństwo przywiązania lub dystansu afektywnego. Co powoduje wzrost kontroli nad sytuacją, a tym samym emocjonalne powiązanie między Agatą i Olą? Po pierwsze, lokalizacja źródła, inaczej mówiąc przyczyny, która wywołuje jakieś zjawisko. Źródłem przekształcenia relacji Ola-Agata jest kamera. Agata grymasem twarzy sugeruje Oli, że kamera nie powinna zaburzyć ich dotychczasowej relacji: równości i przyjacielskości. Agata nie godzi się na to, aby jej wizerunek był obiektem kontroli sprawowanej przez Olę za pośrednictwem kamery wideo.

Po drugie, pisze Lawler (2009, s. 176), „działania negatywne generują złość, jeśli postrzegane są jako będące w zakresie kontroli partnera”. Dzierżenie pieczy nad kamerą, tym samym nad wizerunkami partnerów, wywołuje negatywne emocje. Siostry szybko je usuwają ze swej relacji. Ola odczytuje znaki wysyłane przez Agatę. Władza kamery - rejestracja wizerunków i utrata kontroli nad kontekstem ich prezentacji — od chwili taktownej reakcji Oli, czyli skierowania obiektywu na siebie, dotyczy obu dziewczyn. Cała sekwencja interakcyjna - (1) prezentacja Agaty; (2) regulacja relacji, w której pojawia się nowy aktor - kamera; (3) autoprezentacja Oli przed kamerą; (4) stabilizacja przyjacielskiej relacji - trwa 15 sekund. W kolejnych wpisach wizualnych Agata filmuje Olę równie często, jak Ola - Agatę. Ich relację znów charakteryzuje równość.

Kamera jako obiekt przekształcający relacje grupowe, jako przyczyna zmian stosunków międzyludzkich, w większości dzienników jest pod kontrolą grupy, a nie tylko osoby mającej za zadanie prowadzenie dziennika wizualnego. Pozytywne emocje (przy włączonej kamerze) pojawią się w tych grupach, w których twórca dziennika dzieli się swoją rolą „dziennikowca” $z$ innymi osobami w grupie. Kamera przestaje zawstydzać, gdy filmowany współpracuje z filmującym, gdy operator filmuje siebie, przekazuje kamerę w inne ręce. Krótko mówiąc, gdy poziom kontroli źródeł kształtujących relacje grupowe - w tym przypadku była to kamera - jest wysoki. Każdy w grupie może wziąć kamerę do ręki, pokazać siebie i innych ze swojej perspektywy.

10. DYSPOZYCJA DNIA:

WSPARCIE KONDYCJI FIZYCZNEJ/PSYCHICZNEJ PRZEZ WSPÓŁOBECNYCH

Każda interakcja zogniskowana ma swój formalny przedmiot, na którym skupiają słuch i wzrok kompetentni jej uczestnicy. Jest środa, jesteśmy na Placu Wielkopolskim w Poznaniu, gdzie znajdują się opustoszałe o tej porze

${ }^{20}$ Zob. https://vimeo.com/50435332 
stragany ${ }^{21}$. Z off'u dobiegają odgłosy śmiechu. Film trwa minutę i dwie sekundy. W ciągu tej minuty wiele się dzieje. Adam, przyjaciel Basi, gdy ona włącza kamerę, traci prymat jako podmiot, na którym skupiają się słuchacze. Teraz Basia jest ośrodkiem uwagi. Adam, gdy dostrzega kamerę - urywa zdanie, milknie. Zerwanie spontanicznego zaangażowania skutkuje uczuciem zażenowania, skrępowania, poczuciem wyobcowania i nieładu. Kamera wideo w tym momencie, by użyć celnego pojęcia Goffmana, jest trefnym uczestnikiem interakcji. Koleżanki Basi, zaznajomione z sytuacją projektu dzienników wizualnych, nie krępują się: „Zawsze wybierasz najlepszy moment [by filmować]”, śmieją się, a jedna z nich ironicznie dodaje: filmujesz wtedy, „kiedy jestem nie w sosie". W tym momencie Adam dokonuje projekcji swoich uczuć na koleżankę Basi: ,jesteś nie w sosie, od kiedy ona ma kamerę”. Inna osoba komentuje to, co za chwilę zostanie zarejestrowane przez Basię: „W zeszłym roku większość filmików, jaka została oddana, to z imprez pt. baja bongo". Komentarz ten rozbawia towarzystwo, kamera $z$ trefnego uczestnika staje się ośrodkiem uwagi, tematem humorystycznych komentarzy.

Interakcja to mały system społeczny, „gdzie rodzą się bohaterowie i grasują barbarzyńcy" (Goffman 2006, s.115). Kamera z barbarzyńcy staje się bohaterem, a porządek interakcyjny nie zostaje załamany. Zaangażowanie, humor, komentarze - jak mówi Basia: „wczuwanie” się w sytuację filmowania — wytwarzają rzeczywistość, w której kamera jest ośrodkiem uwagi, a jednocześnie wszystkie te gesty oswajają jej obecność jako elementu interakcji. Dzienniki wizualne pokazują, że ochrona prywatności jest sytuacyjna — zależy od dyspozycji w danym czasie i miejscu. Dyspozycja dnia, minuty zależy od fizycznej kondycji, od psychicznego samopoczucia, ale kształtowana i testowana jest w sytuacjach społecznych.

Czasami mamy zły humor, jesteśmy zmęczeni - stan psychofizyczny wpływa na nasze zachowanie (Kahneman 2012), a interakcja wówczas może być zagrożona. Podobnie jest w przypadku skłonności do dominacji, uległości, podejmowania ryzyka, bycia spiętym bądź na luzie, do uczciwości, skrytości i tak dalej. Dyspozycja lokuje ludzi w zbiorowości, wpływa na kształt zawiązywanych relacji. Fuszerki czy pogubienie się w odgrywanej roli, utrata kontroli nad tożsamością, nad zarządzeniem informacjami przekazywanymi innym w sytuacji publicznej są normalnym trybem interakcyjnym. Gdy pojawia się faux pas, kompetentni uczestnicy ratują twarz tych, którzy popełnili nietakt, gafę. Dyspozycja jest skłonnością, lecz też umiejętnością - można się jej nauczyć poprzez praktykę reagowania na trefnego uczestnika, który łamie niepisane umowy interakcyjne. Adam początkowo protestuje przeciwko filmowaniu. Widzi jednak, że Basia chce i musi włączać kamerę. Akceptuje zatem normy dziennika wizualnego i dostosowuje swoje zachowanie do sytuacji.

${ }^{21}$ Zob. http://vimeo.com/33648269 
Fuszerki nie są w tym przypadku oznaką wyjścia z roli, złamania jej scenariusza, lecz wskaźnikiem autentyczności, tego kim jesteśmy jako osoba. Autentyczne „Ja” nie skrywa się za maską roli społecznej — jest reakcją na to, co dzieje się w otoczeniu. Rozmowa przy straganach na Placu Wielkopolskim przebiega spontanicznie, ale gdy pojawia się trefny uczestnik - kamera - obecne osoby reagują: milkną, ale z czasem zaczynają rozmawiać o filmowaniu. Dyspozycja dnia jest przedspołeczna, gdyż określa sposób wykonania roli społecznej. Jest też społeczna: kształtujemy naszą dyspozycję w kontakcie z innymi ludźmi i ich wytworami. Reakcja Adama na kamerę początkowo jest krótka — „wyłącz to”. Uczy się jednak obcować z „hybrydą”, to jest Basią trzymającą w ręce kamerę. Kolejne filmiki prezentują Adama jako osobę bawiącą się sytuacją filmowania. Dyspozycja jest efektem procesu, w którym uczestnictwo w każdej następnej sytuacji jest poprzedzone doświadczeniem $z$ udziału w przeszłych sytuacjach.

Opisałem, jak „dziennikowcy” budują in situ przestrzeń prywatną pod wszędobylskim okiem kamery wideo. Scott McQuire (2006) stwierdził, że żyjemy $\mathrm{w}$ miastach medialnych: miasto ma swoje przedłużenie w internecie, a smartfon stał się narzędziem rozciagnięcia internetu na materialną tkankę miasta. Miasta nie składają się już tylko, jak powiadał Richard Sennett (1996), z kamienia i ciała; są zbudowane również z bitów. Potraktowałem praktyki „dziennikowców" jako wskaźnik tego, co ludzie robią w zmedializowanych miastach, gdy stają się przedmiotem ekspozycji. Miasto było tłem dla praktyk „dziennikowców“, ale bez tego tła praktyki te nie miałyby miejsca - to w mieście obcy ludzie mogą żyć obok siebie i czerpać korzyści z uprzejmej nieuwagi (Goffman 2012; por. Simmel 1975). Korzyścią tą jest zawarcie prywatnego świata ludzi w publicznej przestrzeni miasta.

Praktyki „dziennikowców” przeczą twierdzeniu, że prywatność ${ }^{22}$, ponoć zagrożona przez media elektroniczne, postrzegane w wielu firmach, organizacjach non-profit i życiu towarzyskim w kategoriach „złodzieja” ${ }^{23}$, jest w stanie oblężenia. W literaturze naukowej i beletrystyce znajdziemy przykłady tego, że odmowa wzięcia udziału w spektaklu online jest przejawem samolubstwa (zob. Atwood 2013; por. Illouz 2010). Jednak w codziennej interakcji w skali mikro jednostki stosują różne techniki, aby podtrzymać delikatną równowagę między światem intymnym a publicznym. Ludzie spontanicznie wytwarzają reguły

22 Prywatność można pojmować na wiele sposobów. Niektórzy (zob. DeCew 2015) bronili prywatności jako przestrzeni, w której jednostka może kontrolować informacje o sobie samej; inni podkreślali, że prywatność jest niezbędna do wytworzenia poczucia autonomii i godności; jeszcze inni twierdzili, że bez prywatności nie może istnieć intymność. Feministyczna krytyka prywatności zwracała uwagę, że jej specjalny status jest szkodliwy, ponieważ służy za tarczę, welon, zasłonę dla uciszania, wykorzystywania, maltretowania kobiet i innych istot (dzieci, starców, zwierząt) przez mężczyzn.

${ }^{23}$ Moja prywatność jest przepustką do twojej prywatności, jeśli nie dzielę się własną prywatnością, ograbiam się z twojej prywatności (zob. Atwood 2013). 
interakcyjne chroniące ich prywatność w sytuacjach, w których biorą udział jako podwójne ciało - materialne tu i teraz oraz wirtualne, czyli w kontekście, nad którym nie mają niemal żadnej kontroli. Dzienniki wizualne są tego śladem. Miasto jest domeną prywatności, tak samo jak jest domeną wspólnego uczestnictwa obywateli w sprawach polis. Można wysunąć postulat, że ochroną prywatności jednostek powinny zająć się rządy i korporacje, ale też architekci, urbaniści, planiści, humaniści. Spontaniczne reguły tworzone przez ludzi w codziennych interakcjach stanowią wskazówkę, jak zarządzać miastem, kreować jego architekturę. Biblią życia miejskiego stała się dziś książka Jane Jacobs Śmierć $i$ życie wielkich miast Ameryki (2014 [1961]), słowami-kluczami dyskusji o mieście „partycypacja”, „ludzka skala”, „dialogiczność”, „bycie razem”. Czasem potrzebna jest jednak chwila wytchnienia, bycie samemu.

Elementem architektonicznym przeplatającym to, co prywatne, $z$ tym, co publiczne, niegdyś było okno - przepuszczało lub zatrzymywało gwar ulicy albo dźwięki mieszkania; wpuszczało powietrze albo dawało wytchnienie od ograniczonego horyzontu ścian pomieszczenia. Dziś okno jest coraz bardziej statyczne i stanowi nieprzepuszczalną barierę oddzielającą ludzi od siebie. Potrzebne są nam miejsca bez kamer CCTV, anty-WiFi cold spoty, w których urządzenia elektroniczne miałyby odcięty dostęp do internetu, co czyniłoby nas niedostępnymi dla powiadomień, wiadomości i reklam; albo działania takie jak The Sentient City Survival Kit (2010) Marka Sheparda — zestaw narzędzi pozwalających na hakowanie aplikacji miejskich (np. powiadomień o obecności znajomych w pobliżu) i monitoringu miejskiego. Warto zajrzeć do średniowiecznych i renesansowych kościołów, do bibliotek, do budynków teatrów, aby analizować przestrzeń indywidualnej refleksji w miejscach publicznych. Potrzebne są nam przestrzenie wielofunkcyjne, w których św. Franciszek z Asyżu spotkałby się z Jane Jacobs z Nowego Jorku.

Równowaga między przestrzenią publiczną a prywatną jest stosunkowo nowym wynalazkiem. W starożytnym Egipcie, Indiach czy Mezopotamii nie było skwerów czy placów. Były dwory usytuowane na zewnątrz świątyni i domów królewskich (Kimmelman 2016). W siedemnastowiecznej Francji prywatne czynności higieniczne czy prokreacyjne odbywały się w tych samych miejscach, w których wspólnie się pracowało, jadło, handlowało (Darnton 2012). Delikatna równowaga między prywatnym i publicznym stała się częścią życia osiemnasato- i dziewiętnastowiecznej burżuazji ${ }^{24}$ i rodzącej się klasy średniej (Abbott 2015; por. Sennett 1996). Nie jest wcale pewne, że przetrwa ta równowaga, do której dostosowane są współczesne miasta. Pytanie o przestrzeń

${ }^{24}$ Życie prywatne burżuazji z okresu belle époque stanowi obszar nader ściśle określony. Chłopi, robotnicy, biedota żyją tak jak żyło się kiedyś: jadają, śpią, wykonują pracę, uprawiają seks $\mathrm{w}$ jednym pomieszczeniu. Noszą też jeden typ ubioru w domu i na ulicy. Ale życie burżuazji jest inne. Erotyzm, czynności higieniczne, organy płciowe stały się sprawą prywatną; ciało i jego reakcje zostały poddane mentalnej kontroli — jednostki zaszywały się w przestrzeni prywatnej nie tylko, aby odpocząć, ale by się modlić, medytować, badać swoją psychikę. 
wspólną zrównoważoną przez przestrzeń intymną coraz częściej pojawia się wraz informacjami na temat prekaryzacji klasy średniej (Standing 2014); coraz większej przepaści między bogatymi a już nie biednymi, lecz klasą średnią (Pikkety 2015); rozciągnięcia sfery pracy na przestrzeń domową, skwery, place, parki, ulice (Spiegel, Forlano, Bacigalupo 2011); grodzenia i prywatyzowania miejskiej przestrzeni publicznej (Shenker 2015); ataków terrorystycznych, które niszczą wyobrażenia o bezpiecznych ulicach, stacjach metra czy kawiarniach miast europejskich (Gessen 2016). „Dziennikowcy” spontanicznie tworzyli praktyki ochronne, aby pozostać sobą — osobami, które z jednej strony współżyją w tej samej przestrzeni z obcymi ludźmi, a z drugiej zachowują pewną dozę intymności, odrębności. Mówiąc inaczej, „dziennikowcy”, choć w bardzo różny sposób, realizowali w swych praktykach miejski styl życia.

\section{BIBLIOGRAFIA}

Abbott Andrew, 2015, The Future of the Social Sciences (http://home.uchicago.edu/aabbott/Papers/ Marc\%20Bloch\%20Lecture\%20Pre\%20Trans.pdf [14.06.2016]).

Atwood Margaret, 2013, When Privacy Is Theft, „The New York Review of Books”, t. 60, nr 18 (http://www.nybooks.com/articles/2013/11/21/eggers-circle-when-privacy-is-theft [14.06. 2016]).

Darnton Robert, 2012 Wielka masakra kotów i inne epizody francuskiej historii kulturowej, tłum. Dorota Guzowska, Wydawnictwo Naukowe PWN, Warszawa.

DeCew Judith, 2015, Privacy, w: Edward N. Zalta (red.), The Stanford Encyclopedia of Philosophy (Spring 2015 Edition), (http://plato.stanford.edu/archives/spr2015/entries/privacy [15.01. 2014]).

Gessen Masha, 2016, Terrorism: The Wrong Conversation, „The New York Review of Books” (http:// www.nybooks.com/daily/2016/06/13/terrorism-wrong-conversation-orlando-shooting [14. 06.2016]).

Goffman Erving, 2006, Rytuat interakcyjny, tłum. Alina Szulżycka, Wydawnictwo Naukowe PWN, Warszawa.

Goffman Erving, 2012, Zachowania w miejscach publicznych, tłum. Olga Siara, Wydawnictwo Naukowe PWN, Warszawa.

Halpern Sue, 2013, Are We Puppets in a Wired World?, „New York Review of Books”, t. 60, nr 17 (http://www.nybooks.com/articles/archives/2013/nov/07/are-we-puppets-wired-world [15. 01.2014]).

Habermas Jürgen, 2007, Strukturalne przeobrażenia sfery publicznej, tłum. Wanda Lipnik, Małgorzata Łukasiewicz, Wydawnictwo Naukowe PWN, Warszawa.

Illouz Eva, 2010, Uczucia w dobie kapitalizmu, tłum. Zygmunt Simbierowicz, Oficyna Naukowa, Warszawa.

Jacobs Jane, 2014, Śmierć i życie wielkich miast Ameryki, tłum. Łukasz Mojsak, Fundacja Bęc Zmiana, Warszawa.

Kahneman Daniel, 2012, Pułapki myślenia. O myśleniu szybkim i wolnym, tłum. Piotr Szymczak, Media Rodzina, Poznań.

Kimmelman Micheal, 2016, The Craving for Public Squares, „New York Review of Books”, t. 63, nr 6 (http://www.nybooks.com/articles/2016/04/07/craving-for-public-squares [14.06.2016]).

Krajewski Marek, 2013, W kierunku relacyjnej koncepcji uczestnictwa w kulturze, „Kultura i Społeczeństwo", nr 1. 
Latour Bruno, 2010, Splatajac na nowo to, co społeczne. Wprowadzenie do teorii aktora-sieci, tłum. Aleksandra Derra, Krzysztof Abriszewski, Universitas, Kraków

Lawler Edward J, 2009, Teoria afektu w wymianie społecznej, tłum. Maja Biernacka, w: Alekander Manterys, Janusz Mucha (red.), Nowe perspektywy teorii socjologicznej, Nomos, Kraków.

McQuire Scott, 2006, The Politics of Public Space in the Media City, „First Monday”, wydanie specjalne, nr 4 (http://firstmonday.org/ojs/index.php/fm/article/view/1544/1459 [05.06.2016]).

Mendelson Edward, 2016, In the Depths of the Digital Age, „New York Review of Books”, t. 63, nr 11 (http://www.nybooks.com/articles/2016/06/23/depths-of-the-digital-age [05.06.2016]).

Piketty Thomas, 2015, Kapitał w XXI wieku, tłum. Andrzej Bilik, Wydawnictwo Krytyki Politycznej, Warszawa.

Sennett Richard, 1996, Ciało i kamień. Czlowiek i miasto w cywilizacji zachodu, tłum. Magdalena Konikowska, Marabut, Gdańsk.

Shenker Jack, 2015, Privatised London: The Thames Path walk that Resembles a Prison Corridor (http:// www.theguardian.com/cities/2015/feb/24/private-london-exposed-thames-path-riverside-w alking-route [05.06.2016]).

Simmel Georg, 1975, Mentalność mieszkańców wielkich miast, w: Georg Simmel, Socjologia, Państwowe Wydawnictwo Naukowe, Warszawa.

Spiegel Dana, Forlano Laura, Bacigalupo Tony, 2011, Situating Knowledge Work in Contemporary Public Spaces, w: Shepard Mark (red.), Sentient City. Ubiquitous Computing, Architecture, and the Future of Urban Space, The Architecture League of New York-The MIT Press, London-New York.

Standing Guy, 2014, Prekariat, tłum. Paweł Kaczmarski, Mateusz Karolak, Wydawnictwo Naukowe PWN, Warszawa.

\section{HOW IS PRIVATE SPACE CONSTRUCTED IN THE CONTEMPORARY CITY? AN ANALYSIS OF VISUAL DIARIES}

\section{Summary}

This article is devoted to the relation between privacy and behaviour in public places. It has already been more than half a century since Erving Goffman published his notes on the social organization of gatherings. Today, the context for meetings in public places is round-the-clock monitoring-exposing oneself online, giving other persons access to one's privacy through internet applications, and being under the eye of the camera 24 hours a day. This context means that the delicate balance between-to use Goffman's terminology - the stage and the wings has been disturbed. On the basis of field material (visual diaries kept by over a dozen persons in the Poznan area), the author concludes that people spontaneously create privacy shields. He presents ten grassroots protective strategies to show that people in contemporary cities spontaneously balance what is private with what is public.

\section{Key words / słowa kluczowe}

privacy / prywatność; privacy shields / osłony prywatności; behavior in public places / zachowanie w miejscu publicznym; visual diary / dziennik wizualny; Internet/internet; Erving Goffman 